Badiou and Politics

POST - CONTEMPORARY INTERVENTIONS

Series Editors: Stanley Fish and Fredric Jameson 



\section{Badiou and Politics}

BRUNO BOSTEELS

Duke University Press DURHAM \& LONDON 2011 
(C) 2011 Duke University Press

All rights reserved

Printed in the United States of America on acid-free paper $\infty$

Designed by Jennifer Hill

Typeset in Arno Pro by Keystone Typesetting, Inc.

Library of Congress Cataloging-in-Publication Data

appear on the last printed page of this book. 
for Simone, Lucas, and Manu 
